\title{
A brief multi-disciplinary review on antimicrobial resistance in medicine and its linkage to the global environmental microbiota
}

\section{Cantas ${ }^{1 *}$, Syed Q. A. Shah ${ }^{1}$, L. M. Cavaco ${ }^{2}$, C. M. Manaia ${ }^{3}$, F. Walsh ${ }^{4}$, M. Popowska ${ }^{5}$, H. Garelick ${ }^{6}$, H. Bürgmann? and H. Sørum ${ }^{1}$}

${ }^{1}$ Department of Food Safety and Infection Biology, Norwegian School of Veterinary Science, Oslo, Norway

2 Research Group for Microbial Genomics and Antimicrobial Resistance, National Food Institute, Technical University of Denmark, Kgs Lyngby, Denmark

${ }^{3}$ Centro de Biotecnologia e Química Fina, Escola Superior de Biotecnologia, Centro Regional do Porto da Universidade Católica Portuguesa, Rua Dr. António Bernardino Almeida, Porto, Portugal

${ }^{4}$ Bacteriology, Agroscope Changins-Wädenswil, Wädenswil, Switzerland

${ }^{5}$ Department of Applied Microbiology, Institute of Microbiology, University of Warsaw, Warsaw, Poland

${ }^{6}$ Department of Natural Sciences, Middlesex University, London, UK

7 Department of Surface Waters - Research and Management, Eawag, Swiss Federal Institute for Aquatic Science and Technology, Kastanienbaum, Switzerland

Edited by:

Stefania Stefani, University

of Catania, Italy

\section{Reviewed by:}

Aixin Yan, The University of

Hong Kong, Hong Kong

Ingeborg M. Van Geijlswijk,

Utrecht University, Netherlands

\section{*Correspondence:}

L. Cantas, Department of Food

Safety and Infection Biology, Section

for Microbiology, Immunology and

Parasitology, Norwegian School of

Veterinary Science, PO Box 8146

Dep. NO-0033 Oslo, Norway.

e-mail: leon.cantas@nvh.no
The discovery and introduction of antimicrobial agents to clinical medicine was one of the greatest medical triumphs of the 20th century that revolutionized the treatment of bacterial infections. However, the gradual emergence of populations of antimicrobial-resistant pathogenic bacteria resulting from use, misuse, and abuse of antimicrobials has today become a major global health concern. Antimicrobial resistance (AMR) genes have been suggested to originate from environmental bacteria, as clinically relevant resistance genes have been detected on the chromosome of environmental bacteria. As only a few new antimicrobials have been developed in the last decade, the further evolution of resistance poses a serious threat to public health. Urgent measures are required not only to minimize the use of antimicrobials for prophylactic and therapeutic purposes but also to look for alternative strategies for the control of bacterial infections. This review examines the global picture of antimicrobial resistance, factors that favor its spread, strategies, and limitations for its control and the need for continuous training of all stake-holders i.e., medical, veterinary, public health, and other relevant professionals as well as human consumers, in the appropriate use of antimicrobial drugs.

Keywords: antimicrobial resistance, human and veterinary medicine, environment, soil, wastewater, resistance genes

\section{BACKGROUND}

Arguably one of the greatest examples of serendipity in science was the discovery of natural antimicrobials between Alexander Fleming and Ernest Duchesne. Although Fleming generally holds the reputation of the discovery of penicillin in 1928, a French medical student, Ernest Duchesne (1874-1912), originally discovered the antimicrobial properties of Penicillium earlier, in 1896. He observed Arab stable boys that kept their saddles in a dark and damp room to encourage mold to grow on them, which they said helped heal saddle sores. Curious, Duchesne prepared a suspension from the mold and injected it into diseased guinea pigs along with a lethal dose of virulent typhoid bacilli and still all animals remained healthy. His work, however, was ignored because of his young age and unknown status (Pouillard, 2002). In a way, with the success of the natural antibiotic penicillin and the synthetic antimicrobial sulfonamides in the first half of the 20th century, the modern antimicrobial revolution began. Since then, new natural antimicrobial compounds were discovered and many semi-synthetic and synthetic antimicrobial drugs were created to combat bacterial infections. Thus, antimicrobials have been extremely important corner stones of modern medicine since the last half of the previous century. Antimicrobial drugs have saved millions of people from lifethreatening bacterial infections and eased patients' suffering. Today, the treatment of bacterial infections is once again becoming increasingly complicated because microorganisms are developing resistance to antimicrobial agents worldwide (Pouillard, 2002; Levy and Marshall, 2004; Alanis, 2005; Pallett and Hand, 2010).

A causal relationship has been demonstrated between the increased use of antimicrobials in both human and veterinary medicine, the greater movement of people, as well as domestic and wild animals, the increased industrialization and the increased prevalence of antimicrobial-resistant bacteria (Holmberg et al., 1987; Cheng et al., 2012). Antimicrobial resistance (AMR) was identified in pathogenic bacteria concurrently with the development of the first commercial antibiotic produced by microorganisms, penicillin (Abraham and Chain, 1940). Although the first concerns about drug-resistant bacteria appeared in hospitals, where most antimicrobials were being used 
(Levy, 1998), the importance of AMR was already recognized in 1969 both in humans and veterinary medicine as stated in the Swan Report (Swann, 1969). Further research showed that the origin and spread of AMR is, in fact, a very complex problem. Hence, there cannot be a single solution for minimizing AMR; rather a coordinated multi-disciplinary approach will be required to address this issue (Serrano, 2005; Smith et al., 2009). We must also recognize that wherever antimicrobials are used, AMR will inevitably follow.

The purpose of this review is to highlight the problem of resistance to antimicrobials with its consequences, including how the spread of AMR could be limited. We highlight how the numerous useful applications of antimicrobials led to AMR in different ecological locations (Figure 1), aiming to unify the many important aspects of this problem. Finally we advocate the need for teaching and continuous training of all stake-holders (i.e., medical, veterinary, public health, and other relevant professionals) as well as human consumers of antimicrobial drugs, in the appropriate use of antimicrobials.

\section{THE HUMAN MEDICINE AND ANTIMICROBIAL RESISTANCE EMERGENCE OF ANTIMICROBIAL RESISTANCE AND ITS COST}

In human medicine AMR is as old as the clinical usage of antimicrobial compounds. Antimicrobial-resistant pathogens have been observed soon after the introduction of new drugs in hospitals where antimicrobials are intensively used (Levy, 1998).

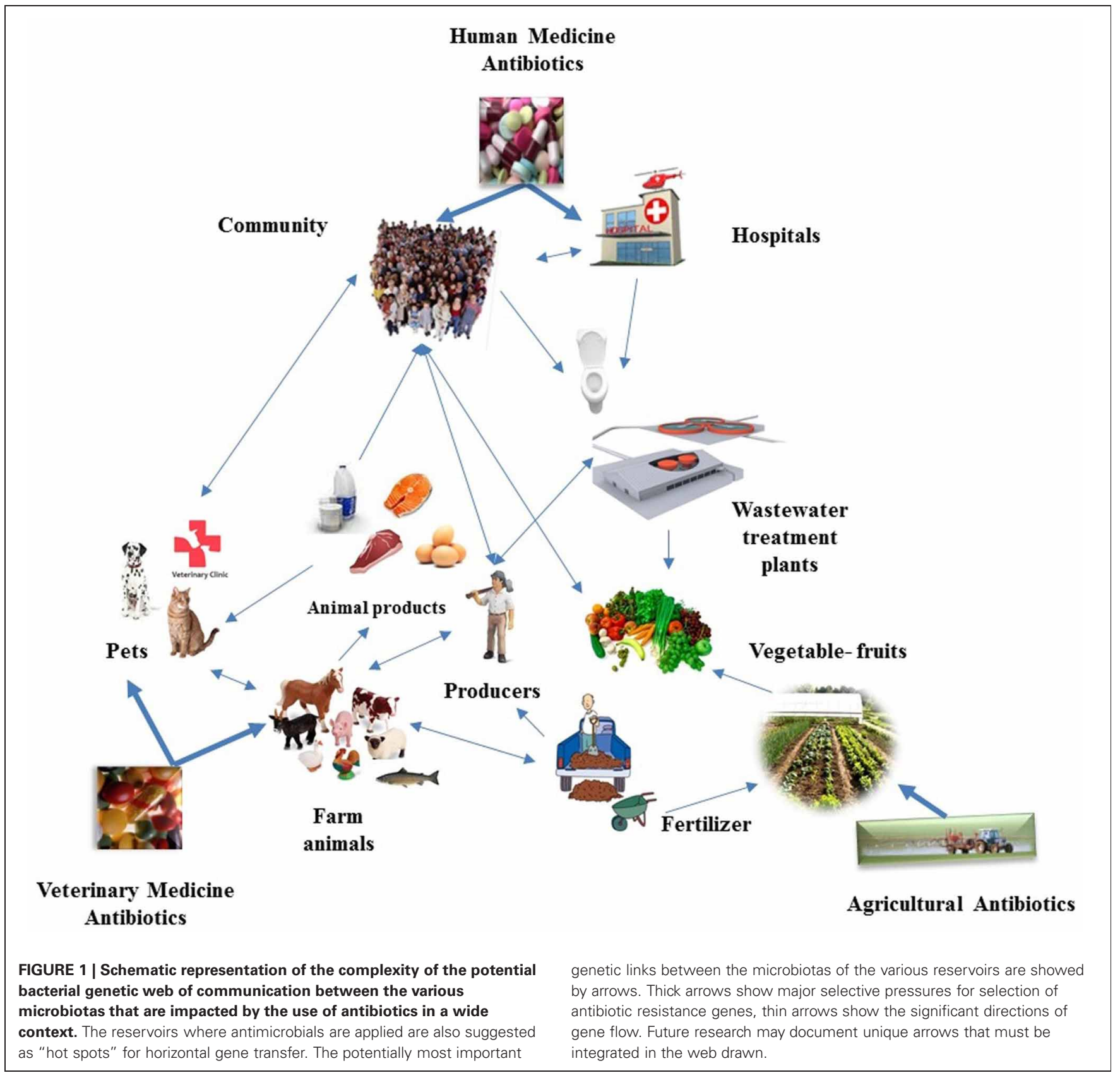


Consequently, AMR in the context of human medicine has dominated the literature for a long time (Figure 2). Over the years, and continuing into the present, almost every known bacterial pathogen and numerous human commensals have developed resistance to one or more antimicrobials in clinical use (Table 1). Extended-spectrum $\beta$-lactamases (ESBL) are the ones most often encountered in the hospital (intensive care) setting. Methicillinresistant Staphylococcus aureus (MRSA) and vancomycin-resistant enterococci (VRE) have also been found to have a significant nosocomial ecology (Otter and French, 2010). In addition, ESBL positive bacteria and MRSA infections are increasingly detected in the community. Furthermore, the increase in fluoroquinolone resistance due to target-site mutations and the worldwide emergence of plasmid-mediated quinolone resistance genes may represent a major challenge in future given the critical importance of this antimicrobial therapy (Cattoir et al., 2007; Strahilevitz et al., 2009). Carbapenems are the last line of defense against the non-Enterobacteriaceae pathogens, such as Pseudomonas aeruginosa and Acinetobacter baumannii (Brown et al., 1998). However, since the first description of the bla OXA genes, there has been a worldwide increase in the dissemination of new resistance determinants conferring carbapenem resistance. For example, the Klebsiella pneumoniae carbapenemase (KPC) type enzymes, Verona integron-encoded metallo- $\beta$ lactamase (VIM), Imipenemase Metallo- $\beta$-lactamase (IMP) and New Delhi metallo- $\beta$-lactamase (NDM), and the OXA-48 type of enzymes have been isolated from a number of bacterial genera irrespective of their geographical distribution (Kumarasamy et al., 2010; Walsh et al., 2011). Carbapenemase resistance mechanisms are found among Escherichia coli and Klebsiella isolates in hospital settings, and to a lesser extent also in the community, thus healthy human carriers begin to be a concern (Nordmann et al., 2012). Furthermore, carbapenemase-producing organisms have also been isolated from farm animals (Fischer et al., 2012).

\section{Record count 'Medical and veterinary research'}

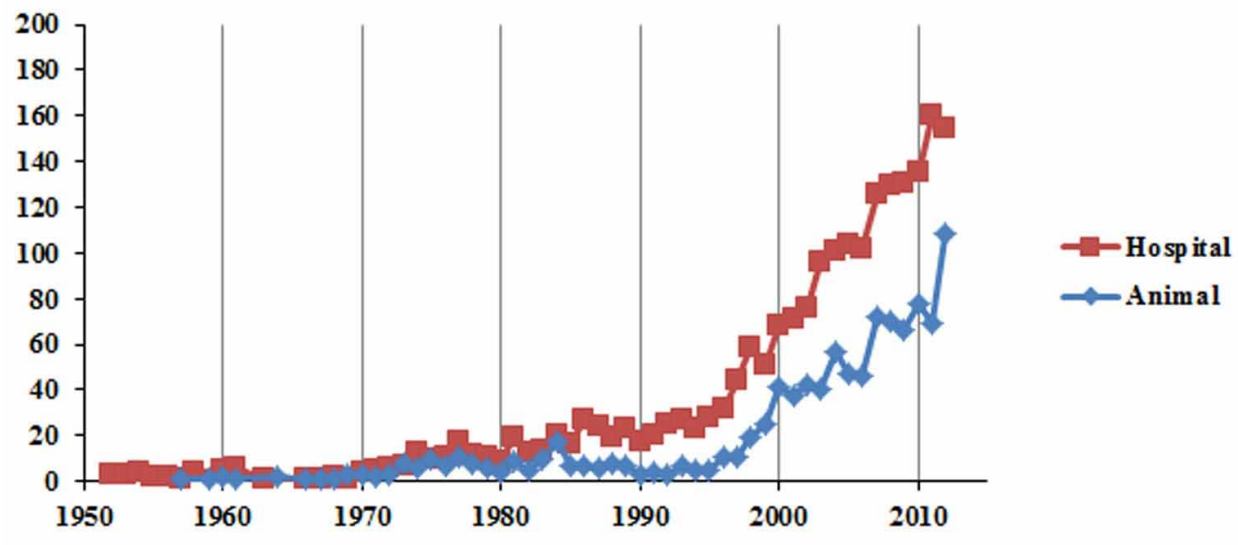

Record count 'Environmental antibiotics resistance'

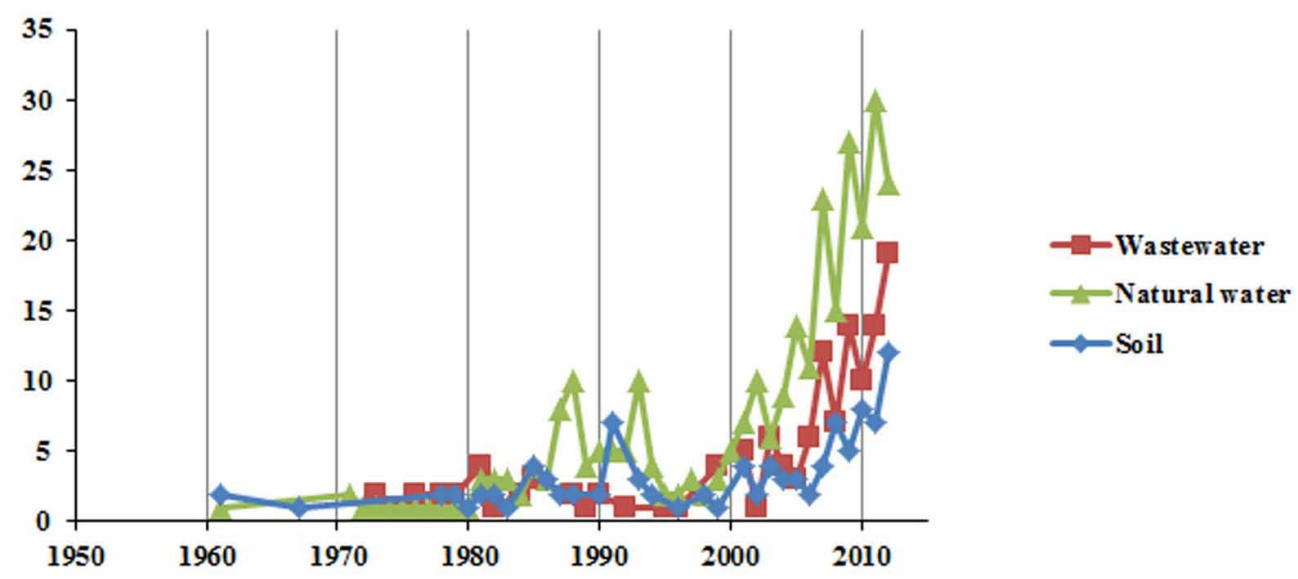

FIGURE 2 | The change in number of antimicrobial resistance related published research papers in different subdisciplines and covering different environments. The data for the graphs were obtained by searching the ISI web of science for publications with titles matching the query terms (antibioti* OR antimicro*) AND resistan* AND the following specific terms:
Hospital, (hospital* OR patient* OR clinic*); Animal, (animal* OR veterinary* OR livestock* OR pig* OR cow* OR chicken* OR poultry); Wastewater, (wastewate* OR sewage); Natural water, (wate* OR lake OR river OR ocean OR sea); Soil, (soil* OR sediment* OR rhizosphere*) (Source: http://apps. isiknowledge.com/). The search was performed on 06/03/2013. 
Table 1 | Antimicrobial resistance detection in some important pathogens soon after arrival of the "magic bullets" into the market.

\begin{tabular}{|c|c|c|c|c|}
\hline Year & Bacteria & Drug resistance & Comments & References \\
\hline 1948 & Staphylococcus aureus & Penicillin & $\begin{array}{l}\text { In British civilian hospitals soon } \\
\text { after the introduction of penicillin }\end{array}$ & $\begin{array}{l}\text { Barber and } \\
\text { Rozwadowska-Dowzenko, } 1948\end{array}$ \\
\hline 1950's-1960's & $\begin{array}{l}\text { Escherichia coli, Shigella spp., and } \\
\text { Salmonella enterica }\end{array}$ & Multiple drugs & & $\begin{array}{l}\text { Watanabe, 1963; Olarte, 1983; } \\
\text { Levy, } 2001\end{array}$ \\
\hline
\end{tabular}

VRE, Vancomycin-Resistant Enterococcus; ESBL, Extended-spectrum $\beta$-lactamase; MRSA, methicillin/oxacillin-resistant Staphylococcus aureus; $Q^{R}$, Quinolone resistant; MDR, Multi-drug resistant.

\section{HUMAN MOBILITY - THE DIRECT AND INDIRECT IMPACT ON HUMAN PATHOGENS}

The increasing cross-border and cross-continental movements of people has a major impact on the spread of multi-resistant bacteria (Linton et al., 1972; Arya and Agarwal, 2011; Cheng et al., 2012). The emergence and global spread of the international clone 1 of penicillin-resistant Streptococcus pneumoniae (Klugman, 2002) and the recently occurring New Delhi Metallo- $\beta$-lactamase $\left(\right.$ bla $\left.a_{\mathrm{NDM}}-1\right)$ producing Enterobacteriaceae, which inactivates all $\beta$-lactam antimicrobials, including carbapenems, are good examples. The $b l a_{\mathrm{NDM}}-1$ appears to have originated in the Indian subcontinent and subsequently could be found in North America, the United Kingdom, and other European countries by the movement of people (Arya and Agarwal, 2011; Walsh et al., 2011).

The AMR problem remains a growing public health concern because infections caused by resistant bacteria are increasingly difficult and expensive to treat. The consequences of this problem are: longer hospital stay, longer time off work, reduced quality of life, greater likelihood of death due to inadequate or delayed treatment, increases in private insurance coverage and an additional costs for hospitals when hospital-acquired infections occur in addition to the increased overall healthcare expenditure (Roberts et al., 2009; Filice et al., 2010; Korczak and Schöffmann, 2010; Wilke, 2010). Thus, in order to calculate the full economic burden of AMR we have to consider the burden of not having antimicrobial treatment options at all, which in the extreme case would probably cause a breakdown of the entire modern medical system (Alanis, 2005; Falagas and Bliziotis, 2007; Pratt, 2010). In short, everyone will be at risk when antimicrobials become ineffective and the threat is greatest for young children, the elderly, and immune-compromised individuals, such as cancer patients undergoing chemotherapy and organ transplant patients (Tablan et al., 2004).

\section{THE VETERINARY MEDICINE AND AGRICULTURE SECTOR CONSUMPTION AND REGULATION OF ANTIMICROBIAL USE IN ANIMALS}

The antimicrobials, used in veterinary medicine were introduced soon after they became available for the treatment of human diseases from the mid-1940's (Gustafson and Bowen, 1997; McEwen, 2006). Even though some drugs are exclusively designed for veterinary use, most belong to the same antimicrobial classes as those used in human medicine with identical or very similar structures (Swann, 1969; Heuer et al., 2009).

Annually, large quantities of drugs are administered to animals in the agricultural sector worldwide to secure a sufficient amount of food (meat, eggs, and dairy products) to feed a rapidly growing world human population (Vazquez-Moreno et al., 1990; Roura et al., 1992; Rassow and Schaper, 1996). As data collection on antimicrobial use in animals was not harmonized to provide reliable and comparable information, and following a request from the European Commission the European Medicines Agency (EMA), the European Surveillance of Antimicrobial Consumption (ESVAC) programme has been created. The ESVAC programme is responsible for collecting, analyzing, and reporting sales data from European countries and developing an organized approach for the collection and reporting of data on antimicrobial use for animals including annual reporting from EU member states (www.ema.europa.eu/ema/index. jsp?curl=pages/regulation/document_listing/document_listing_ 000302.jsp). During 2007, in 10 European countries the sale of antimicrobial drugs for therapeutic use as veterinary medicine varied from 18 to $188 \mathrm{mg} / \mathrm{kg}$ biomass (Grave et al., 2010).

The administration of antimicrobials to food producing animals can have other purposes than treatment, such as: growth promotion (although now totally banned in Europe and quinolones for the poultry industry are banned in the USA), prophylaxis, and -metaphylaxis (Anthony et al., 2001; Anderson et al., 2003; Casewell et al., 2003; Cabello, 2006). Approximately 70\% of all the antimicrobials administered in animal farming are used for non-therapeutic purposes (Roe and Pillai, 2003).

In the European Union (EU) the use of avoparcin was banned in 1997. Furthermore spiramycin, tylosin, and virginiamycin for growth promotion were banned from use in 1998. All other growth promoters in the feed of food-producing animals were banned in the EU-countries from January 1, 2006 (http:// europa.eu). Data from Denmark showed that animals could be produced at a large scale without the use of growth promoters, 
without adversely affecting the production (Aarestrup et al., 2001; Aarestrup, 2005; Hammerum et al., 2007). In the United States of America, politicians are discussing the introduction of a similar ban on the use of antimicrobials in animal husbandry for growth promotion (http://www.govtrack.us/congress/bills/109/ s742). Despite these bans, in some parts of the world, medically important antibiotics are still routinely fed to livestock prophylactically to increase profits and to ward-off potential bacterial infections in the stressed and crowded livestock and aquaculture environments (Cabello, 2006; Smith et al., 2009; Ndi and Barton, 2012). Because stress lowers the function of the immune system in animals, antimicrobials are seen as especially useful in intensive confinements of animals (Halverson, 2000). The non-therapeutic use of antimicrobials involves low-level exposure through feed over long periods - an optimal way in which to enrich resistant bacterial populations (Sharma et al., 2008; Kohanski et al., 2010; Alexander et al., 2011; Gullberg et al., 2011).

Various monitoring programs around the world have started monitoring AMR and a range of research activities and interventions have shown that antimicrobial usage has a large effect upon selection of AMR in animal production. A rapid and parallel decrease in resistant Enterococcus faecium from pig and poultry has been reported in Denmark after the ban of growth promoters in livestock (Aarestrup et al., 2001). The Norwegian aquaculture industry has produced over one million tons of farmed fish (http://www.ssb.no/fiskeoppdrett_en/) by using only $649 \mathrm{~kg}$ of antimicrobials in 2011 (NORM/NORM-VET, 2011). It is evident from the Danish integrated AMR monitoring and research program (DANMAP) and NORM/NORM-VET Report (NORM/NORM-VET, 2011) that reduction of antimicrobial usage with strict policies may still be the safest way to control the development and spread of AMR in this sector in the future.

\section{ANTIMICROBIAL-RESISTANT BACTERIA IN COMPANION ANIMALS AND ANIMAL HUSBANDRY}

The use of antimicrobials in animal husbandry has for many years actively selected for bacteria which possess genes capable of conferring AMR (Bastianello et al., 1995; Sundin et al., 1995). Consequently, this aspect has also seen much attention in the literature (Figure 2). Despite large differences in methodology, the results of most relevant scientific studies demonstrate that not long after the introduction of antimicrobials in veterinary practice, resistance in pathogenic bacteria, and/or the fecal flora was observed (Caprioli et al., 2000; Jean-Louis et al., 2000). In particular an increased emergence of pathogenic bacteria resistant to antimicrobials has occurred in members of the genera Salmonella, Campylobacter, Listeria, Staphylococcus, Enterococcus, and Escherichia coli. Some resistant strains of these genera are propagated primarily among animals but can subsequently infect people as zoonotic agents (Levy, 1984; Corpet, 1988; Marshall et al., 1990; Giguêre et al., 2007).

In veterinary medicine the use of antimicrobials in companion animals such as pets and horses is restricted to therapeutic purposes only. Companion animals are increasingly treated as family members, in the context of applying advanced antimicrobial treatments to their infectious diseases. For instance, skin infections caused by staphylococci in dogs with or without underlying allergic reactions result in an increasing use of semisynthetic penicillins because of the ineffectiveness of penicillin against penicillinase producing Staphylococcus pseudintermedius (Yoon et al., 2010). Moreover, emerging methicillin-resistant Staphylococcus pseudintermedius (MRSP), methicillin-resistant Staphylococcus aureus (MRSA), and ESBL producing E. coli displaying multidrug resistance has led to increased concern related to AMR in companion animal practice (Bannoehr et al., 2007; Wieler et al., 2011). Increased antimicrobial resistance development and spread in companion animals due to irrational antimicrobial usage, especially overprescribed broad spectrum antimicrobials without precise diagnostics, inevitably cause (1) animal health problem (increased mortality and morbidity), (2) economical problem to the owner (more visits-therapies and prolonged hospitalization), (3) economical problem to the veterinarian (possible loss of customers and high costs for hospital decontamination), and (4) human health problems (risks of zoonotic transmission). Because of this threat small animal veterinarians should prescribe broad spectrum antimicrobials after culturing and educate pet owners to handle infected-antimicrobial treated animals with precaution.

However, emergences of resistance toward antimicrobials which are critically important for human therapy are the most worrisome. These include the recent emergence of ESBL producing and carbapenemase positive Enterobacteriaceae bacteria in animal production (Horton et al., 2011), the emergence of farm associated MRSA ST398 (the main pig associated clone) (Cuny et al., 2010; Kluytmans, 2010; Weese, 2010) and of plasmidmediated quinolone resistance in animal isolates and food products (Poirel et al., 2005; Nordmann et al., 2011). Unfortunately, there are several examples in the literature that show that these are already widespread in Europe and other parts of the world and have a large impact on human health (Angulo et al., 2004; Heuer et al., 2009; Forsberg et al., 2012).

Aquaculture (fish, shellfish, and shrimp farming industries) has developed rapidly in the last decade and has become an important food source (FAO, 2010). Fish pathogenic bacteria often produce devastating infections in fish farms where dense populations of fish are intensively reared. Although modern fish farming relies increasingly on vaccination and improved management to avoid infections (Markestad and Grave, 1997; Midtlyng et al., 2011), still many bacterial infections in fish are regularly treated with antimicrobials in medicated feed or by bath immersion. The most widely used drugs are fluoroquinolones, florfenicol, oxytetracyclines amoxicillin and sulfonamides (Cabello, 2006; Gräslund et al., 2003; Holmström et al., 2003; Primavera, 2006; Soonthornchaikul and Garelick, 2009). By now, most of the fish pathogenic bacteria from fish farms with a history of infections have developed AMR (Colquhoun et al., 2007; Lie, 2008; Sørum, 2008; Farmed Fish Health Report, 2010; Shah et al., 2012a). Furthermore, in some areas of the world, particularly in South-East Asia, integrated farming is a common practice where organic wastes from poultry and livestock are widely used in manuring the fish farms (Hoa et al., 2011; Shah et al., 2012b). It has been reported that antimicrobial residues present in the poultry and livestock waste has provided sufficient selection pressure for the selection of AMR genes, 
increasing the complexity of transmission of bacteria, and resistances between the livestock and aquatic environment (Petersen et al., 2002; Agersø and Petersen, 2007; Hoa et al., 2011; Shah et al., 2012b).

AMR has been detected in different aquatic environments and some resistance determinants have been found to originate from aquatic bacteria. A good example is the recently emerging plasmid-mediated quinolone resistance determinants from the qnr family (Ash et al., 2002; Picao et al., 2008) and CTX-M from aquatic Kluyvera spp. (Decousser et al., 2001; Rodriguez et al., 2004; Ma et al., 2012). In addition, epidemiological and molecular data indicate that some fish pathogens such as Aeromonas are able to transmit and share AMR determinants with bacteria isolated from humans such as E. coli (Rhodes et al., 2000; Sørum, 2006). Similarly, the fish pathogen Yersinia ruckeri have been reported to share AMR plasmid and AMR genes with the bacterium causing human plague (Welch et al., 2007).

\section{ANTIMICROBIAL USE IN PLANT AGRICULTURE}

Streptomycin and oxytetracycline are routinely used for the prophylaxis of fire blight disease (causative agent Erwinia amylovora) in apple and pear orchards. Streptomycin use is strictly controlled within the EU and is only authorized for use on a yearly basis. However, streptomycin use in plant agriculture in the USA has been replaced by oxytetracycline, due to streptomycin resistance development among E. amylovora in the apple orchards. Oxolinic acid had been reported to be used in Israel against fire blight and against rice blight in Japan (Shtienberg et al., 2001). Gentamicin is used in Mexico and Central America to control Fire Blight and various diseases of vegetable crops (Stockwell and Duffy, 2012). However, the role of antimicrobial use on plants is, knowing the AMR crisis in human medicine, the subject of debate (McManus et al., 2002).

\section{DISSEMINATION OF ANTIMICROBIAL-RESISTANT BACTERIA THROUGH FOOD AND FOOD PRODUCTION}

Resistant bacteria can be transferred from animals and plants to humans in many different ways, which can be categorized into three major modes of transmission: (1) through the food chain to people (Roe and Pillai, 2003; Soonthornchaikul and Garelick, 2009), (2) through direct or indirect contact with livestock industry or animal health workers (Levy et al., 1976), (3) through environments which are contaminated with manure in agriculture (http://ec.europa.eu/environment/ integration/research/newsalert/pdf/279na4.pdf) and aquaculture (Petersen et al., 2002; Shah et al., 2012b). The environment contains a great variety of bacteria creating an immense pool of AMR genes that are available for transfer to bacteria that cause human disease (Riesenfeld et al., 2004b; D'Costa et al., 2006). The realization of these links sparked the recent interest in the role and dynamics of environmental AMR (Figure 2).

In addition, other sources are available. For instance, wild animals may also be carriers of antimicrobial-resistant bacteria (Literak et al., 2011). These animals may have close contact to human or farming areas and/or waste and become colonized with resistant strains (Literak et al., 2011; Nkogwe et al., 2011). Interestingly, animals in remote areas have been found to harbor-resistant bacteria (Zhang et al., 2009; Glad et al., 2010; Lang et al., 2010).

\section{ANTIMICROBIAL RESISTANCE IN THE ENVIRONMENT MICROBIAL COMMUNITIES IN SOIL AND ANTIMICROBIAL RESISTANCE}

Research data shows that in diverse soils from various regions of the world, there is a wide dispersion of AMR. One explanation for this phenomenon is the existence of antimicrobial producing bacteria in soil. The Actinomycetes, which are common soil bacteria (Streptomyces, Micromonospora, Saccharopolyspora genus), synthesize over half of all known most clinically relevant antimicrobials e.g., tetracycline, gentamicin, erythromycin, streptomycin, vancomycin, and amphotericin. Bacteria of the genus Bacillus also produce antibiotics, e.g., Bacillus brevis which producing gramicidin (Baltz, 2007). These antimicrobials now also reach the environment from human and animal therapeutics, through manure, sewage, agriculture, etc. Many retrospective and prospective studies have been performed to assess the emergence and selection of AMR in environmental bacteria. The environment is eventually the largest and most ancient reservoir of potential AMR, constituting the environmental "resistome" (Aminov and Mackie, 2007; Allen et al., 2010; D'Costa et al., 2011). Under such powerful selection pressure, it is not surprising that the soil resistome is so diverse (Knapp et al., 2010). The best example illustrating this is the tetracycline resistome. Tetracyclines are an important class of antimicrobials with desirable broad-spectrum activity against numerous pathogens and the widespread emergence of resistance has had a massive impact on these drugs (Thaker et al., 2010). Opportunistic pathogens ubiquitous in the soil for example, Pseudomonas aeruginosa, Acinetobacter spp., Burkholderia spp., and Stenotrophomonas spp. can combine intrinsic resistance to several antimicrobials with a remarkable capacity to acquire new resistance genes (Popowska et al., 2010). Still, little is known about the diversity, distribution, and origins of resistance genes, particularly among the as yet noncultivable environmental bacteria. In uncultured soil bacteria, identified resistance mechanisms comprise efflux of tetracycline and inactivation of aminoglycoside antimicrobials by phosphorylation and acetylation (Popowska et al., 2012). In addition, bacteria resistant to macrolides including the new drug telithromycin have been reported from soil (Riesenfeld et al., 2004a). In a study by (D'Costa et al., 2006), 480 strains of Streptomyces from soil were screened against 21 antimicrobials. Most strains were found to be multi-drug resistant to seven or eight antimicrobials on average, with two strains being resistant to 15 of the 21 drugs. It was also reported that soil is a reservoir for $\beta$-lactamases and these genes, if transferred to pathogens, can then impact human health (Allen et al., 2010). It is supposed that the presence of antibiotics in the environment has promoted the acquisition or independent evolution of highly specific resistance elements. These determinants are located mainly on mobile genetic elements such as plasmids and conjugative transposons, which ensure their spread by horizontal gene transfer. Conjugative, broad-host-range plasmids play a key role in this process (Martinez, 2009; Stokes and Gillings, 2011). Numerous studies have demonstrated that the prevalence of such resistance plasmids in soil is very high 
(Götz et al., 1996). Among the plasmids conferring resistance to antimicrobials, representatives of the incompatibility groups $\mathrm{P}$, $\mathrm{Q}, \mathrm{N}$, and $\mathrm{W}$ have been identified. An example of this type of mobile genetic elements may be the IncP-1 plasmids (Popowska and Krawczyk-Balska, 2013). Results from the scientific literature show that plasmids carrying resistance genes have been identified in pathogenic bacteria of the genus Escherichia, Salmonella, Shigella, Klebsiella, Aeromonas, and Pseudomonas, the genera that can be found in soil and water (Stokes and Gillings, 2011). These plasmids carry determinants for resistance to at least one heavy metal $(\mathrm{Ni}, \mathrm{Cd}, \mathrm{Co}, \mathrm{Cu}, \mathrm{Hg}, \mathrm{Pb}, \mathrm{Zn})$ and antimicrobials of different groups, i.e., tetracyclines, quinolones, aminoglycosides, sulfonamides, $\beta$-lactams, and chemotherapeutics (Sen et al., 2011; Seiler and Berendonk, 2012). Overall these data indicate that soil bacteria constitute a reservoir of resistance determinants that can be mobilized into the microbial community including pathogenic bacteria. Recent studies also indicate a different mechanism of AMR in soil-derived actinomycetes, by engendering mutations in genes encoding the transcriptional and translational apparatus that lead to alterations in global metabolism. This vertically selected AMR includes increased production of secondary metabolites (Derewacz et al., 2013). Very recently evidence for recent exchange of AMR genes between environmental bacteria and clinical pathogens was presented using a high-throughput functional metagenomic approach (Forsberg et al., 2012). In this study it was shown that multidrug-resistant soil bacteria contain resistance gene cassettes against five classes of antimicrobials ( $\beta$-lactams, aminoglycosides, amphenicols, sulfonamides, and tetracyclines) with high nucleotide identity to genes from diverse human pathogens. Therefore, it is important to study this reservoir, which may contribute to the detection of new clinically relevant AMR-mechanisms and/or the multidrug-resistant pathogens that should be avoided from entering medically important bacteria (Torres-Cortés et al., 2011).

\section{ANTIMICROBIAL RESISTANCE IN AQUATIC ENVIRONMENTS}

Water is one of the most important habitats for bacteria, holding complex microbial communities. Not surprisingly, water also contains AMR bacteria. From natural fresh water systems to drinking water, or from sewage to human-engineered water infrastructures, AMR, either intrinsic or acquired, have been reported in aquatic environments worldwide (e.g., Goñi-Urriza et al., 2000; Volkmann et al., 2004; Schwartz et al., 2006; Ferreira da Silva et al., 2007; Böckelmann et al., 2009; Vaz-Moreira et al., 2011; Falcone-Dias et al., 2012). In this respect, given their characteristics, wastewater habitats are particularly important.

\section{WASTEWATER HABITATS AS RESERVOIRS OF ANTIMICROBIAL RESISTANCE}

Among the aquatic environments, wastewater habitats represent the most important reservoir of AMR bacteria and genes. This type of water contains human and animal excretions with abundant doses of commensal and pathogenic antimicrobialresistant bacteria (Yang et al., 2011; Ye and Zhang, 2011, 2013; Novo et al., 2013). Since antimicrobials are not fully degraded in the human and animal body, antimicrobial compounds, their metabolites and transformation products are abundant in urban sewage treatment plants (Segura et al., 2009; Michael et al., 2013). Although proportion of the antimicrobial compounds are transformed and degraded in the environment, the occurrence of these micropollutants is reported worldwide, with antimicrobials of all classes being detected in wastewater habitats in concentrations ranging from $\mathrm{ng}^{-1}$ to $\mathrm{mgL}^{-1}$ (Michael et al., 2013). Simultaneously, urban sewage and wastewater contain AMR bacteria and other pollutants, such as pharmaceutical and personal hygiene products and heavy metals, whose effects on AMR selection are still not very clear (Graham et al., 2011; Oberlé et al., 2012; Patra et al., 2012; Novo et al., 2013). Often, wastewater treatment is not enough to eliminate the antimicrobial residues entering the system (Michael et al., 2013). The consequence is that such micropollutants, exerting selective pressures, may facilitate the selection of AMR bacteria or the acquisition of resistance genes by horizontal gene transfer (Martinez, 2009). Indeed, the relevance of wastewater habitats to the dissemination of AMR among human pathogens as well as commensal and environmental bacteria is increasingly emphasized (Baquero et al., 2008; Marshall and Levy, 2011; Czekalski et al., 2012; Rizzo et al., 2013). Wastewater treatment plants reduce the load of AMR bacteria, but treated water still carries elevated levels of AMR bacteria, and may select for strains with high levels of multidrugresistance (Czekalski et al., 2012). Resistance gene abundance in a stream system could be linked to the input of (treated) wastewater and animal husbandry, demonstrating landscape-scale pollution of natural aquatic systems with AMR (Pruden et al., 2012). The currently available literature demonstrates that most of the AMR genetic elements found in clinical isolates are also detected in wastewater habitats, even shortly after they have been reported in hospitals (Szczepanowski et al., 2009; Rizzo et al., 2013). The occurrence of the same AMR genetic elements in different habitats demonstrates the uniqueness of the resistome, mainly due to rapid dissemination processes, demonstrating the urgent needs for an integrated approach.

Ubiquitous bacteria that can live in the environment and are also able to colonize humans are particularly relevant to the spread of AMR in the environment and the implications to human health. Indeed, numerous studies have reported the occurrence of AMR in ubiquitous bacteria isolated from wastewater habitats, which are also recognized as opportunistic pathogens, mainly nosocomial agents. AMR bacteria of clinical relevance which may be found in the environment comprise, among others, members of the genera Acinetobacter, Enterococcus, Escherichia, Klebsiella, Pseudomonas, and Shigella (Blanch et al., 2003; Reinthaler et al., 2003; Ferreira da Silva et al., 2006, 2007; Watkinson et al., 2007; Novo and Manaia, 2010; Czekalski et al., 2012). In addition, non-cultivable bacteria may also be important either for AMR spread or selection. Indeed, over the last years, the use of culture independent approaches brought additional insights into the abundance and diversity of resistance genes in wastewaters and into the effects of antimicrobials on the bacterial communities (Volkmann et al., 2004; Czekalski et al., 2012; Oberlé et al., 2012; Novo et al., 2013). In particular, several studies presented evidence that in wastewater habitats there is a high potential for horizontal gene transfer, mediated by plasmids and facilitated by integrons (Tennstedt et al., 2003; Szczepanowski 
et al., 2008; Moura et al., 2010; Zhang et al., 2011). Despite the importance of wastewater as a reservoir for AMR genes, and the relevance of wastewater treatment to control resistance spread, to date the number of studies that have been published remains relatively low (Figure 2 ).

Nevertheless, over the last decades the knowledge in this area has increased considerably and the importance of wastewater treatment systems for the spread of AMR is unequivocally demonstrated. Therefore, it is now possible to address some specific questions which we expect to be a focus of the research in this area in the coming years. Examples of these issues are (1) the identification of the conditions that may enhance or mitigate the occurrence of horizontal gene transfer and selection of AMR (which pollutants, which concentrations, temperature, $\mathrm{pH}$, hydraulic residence time of wastewater treatment, etc.); (2) the classification and quantification of risk, e.g., the likelihood that an AMR bacterium or gene from wastewater habitats reach humans and causes issues for human health; (3) the improvement of wastewater treatment processes in order to minimize the loads of antimicrobial-resistant bacteria and genes in the final effluent (Dodd, 2012).

\section{THE ANTIMICROBIAL RESISTANCE GENE POOL}

AMR genes can be differentiated depending on the genetic event that is required for acquiring an AMR phenotype. These include genes that are acquired by horizontal gene transfer and genes that are present in the bacterial genome and that can encode AMR following gene mutations or activation (Olliver et al., 2005).

AMR features evolve as a consequence of permanent exchange of and ever new recombinations of genes, genetic platforms, and genetic vectors. Many of these genes are not primarily resistance genes, but belong to the hidden resistome, the set of genes able to be converted into AMR genes (Baquero et al., 2009). As evidenced by our discussion above, microbial organisms harboring these genes are present naturally in all kinds of environments, but also released into water and soil from organisms, including humans, where they evolve or increase in abundance under direct selection from exposure to antimicrobials. At the same time, antimicrobials (often at low concentrations), disinfectants, and heavy metals are disseminated into the water as well, and may act as selective factors fostering the evolution of new AMR features (Cantas et al., 2012a,b,c; Cantas et al., unpublished). The rate of degradation of antimicrobials in the environment varies and is dependent on a range of environmental conditions, for example: temperature, available oxygen, $\mathrm{pH}$, presence of alternative sources of organic and inorganic discharges as described in Table 2.

\section{HOW TO SLOW DOWN THE SPREAD AND EVOLUTION OF AMR?}

In this review we have emphasized that the problem of AMR evolution and dissemination is multifaceted and involves clinical, agricultural, technical, and environmental systems. Similarly strategies to deal with the impending AMR crisis have to take this complexity into account.

The overuse of antimicrobials needs to be limited or reduced in human medicine, veterinary medicine, agriculture, and aquaculture. Ideally, the use of antimicrobials in agriculture should be eliminated. Intensive programs to educate both patients and
Table 2 | Degradation rates of various antimicrobials in soil.

\begin{tabular}{|c|c|c|c|}
\hline $\begin{array}{l}\text { Class of } \\
\text { antimicrobial }\end{array}$ & $\begin{array}{l}\text { Degradation } \\
{[\%]}\end{array}$ & $\begin{array}{l}\text { Time } \\
\text { [d] }\end{array}$ & References \\
\hline Macrolides & $0-50$ & $5-30$ & Thiele-Bruhn, 2003* \\
\hline Sulfonamides & $0-50$ & $22-64$ & Thiele-Bruhn, 2003 \\
\hline Fluoroquinolones & $0-30$ & $56-80$ & $\begin{array}{l}\text { Hektoen et al., 1995; } \\
\text { Thiele-Bruhn, } 2003\end{array}$ \\
\hline Tetracycline & $0-50$ & $10-180$ & $\begin{array}{l}\text { Björklund et al., 1991; } \\
\text { Thiele-Bruhn, } 2003\end{array}$ \\
\hline Aminoglycosides & 0 & 30 & Thiele-Bruhn, 2003 \\
\hline$\beta$-lactams & $0-50$ & 30 & Thiele-Bruhn, 2003 \\
\hline Imidasoles & 50 & $14-75$ & Thiele-Bruhn, 2003 \\
\hline Polypeptides & $12-90$ & $2-173$ & Thiele-Bruhn, 2003 \\
\hline
\end{tabular}

* This reference does not include the modern macrolides with very long elimination half-lives. For instance, Tulathromycine has an half live (so 50\% degraded, not nearly 100\%) in soil of 99 days (Pfizer, personal communication 2013).

physicians in reducing antimicrobial overuse should be implemented. Following the analysis more than 500 scientific articles, it has been suggested that the elimination of non-therapeutic use of antimicrobials in food animals, will lower the burden of AMR in the environment, with consequent benefits to human and animal health (FAAIR Scientific, 2002; Swartz, 2002).

Better management techniques and strict legislation in the use of antimicrobials for therapeutic use in humans and in animals will reduce the risk of development of AMR (Cunha, 2002; Defoirdt et al., 2011; Midtlyng et al., 2011). For example, the prevention of nosocomial transmission of multi-drug resistant bacteria is possible with active routine surveillance programs that can identify colonized patients. Numerous studies have demonstrated that such a "search and containment" approach and/or a "search and destroy" approach in which an attempt is made to eliminate carriage of the organism can reduce the incidence of hospital-acquired infections and be cost-saving (Muto et al., 2003).

New management techniques in the animal husbandry, such as organic farming, need to be thoroughly investigated to ensure that these are viable alternatives that help to reduce the potential for selection of AMR bacteria. Samples from organically farmed poultry showed a significantly lower level of AMR in intestinal bacteria such as E. coli and Campylobacter (Soonthornchaikul et al., 2006). However from organically farmed cattle no significant differences were obtained in microbiological contamination. E. coli and S. aureus isolates were found to have significantly lower rates of AMR in organically raised cattle (Sato et al., 2005). More studies are needed (1) to determine the reasons of antimicrobial usage in the farms by veterinarians, (2) to compare and update the recommended treatment protocols for veterinarians throughout different countries, (3) to evaluate the impact of other factors other than AMR development in bacteria: e.g., immune responsestress has been indicated to correlate with resistance genetic element shuffling among gut microbiota in different animal models, 
such as: atlantic salmon, zebrafish, neonatal piglets, and cats (Cantas et al., 2011, 2012a,b,c, 2013). Animal welfare parameters under intensive production such as stress should be investigated in future studies with regards to control of resistance development in animal husbandry.

Vaccination and improved hygienic measures are among the important cornerstones in controlling infectious diseases and consequently aid in reducing AMR (Potter et al., 2008). The Norwegian aquaculture may serve as a good example by reduction in the use of antimicrobials from around 50 tons in the late 1980 's to less than $1000 \mathrm{~kg}$ per annum after introduction of effective vaccines against devastating fish diseases like furunculosis and vibriosis (Midtlyng et al., 2011; NORM/NORM-VET, 2011).

The use of pre- and probiotics to improve the health and performance of livestock might be a good alternative to growth promoters. This is an important biological control aiming to reduce outbreaks of infectious diseases and which in turn would minimize the use of antimicrobials in livestock and aquaculture for therapeutic purposes (Verschuere et al., 2000; Callaway et al., 2008).

The issue of dissemination and possible long-term enrichment of AMR and AMR genes in the environment (Knapp et al., 2008) needs to be studied further, with specific regards to the actual risks associated with it. However, taking action is already possible today. For example, several treatment methods for waste and wastewater disinfection and removal of micropollutants, including antimicrobials, are available. These include various chemical disinfections, UV treatment, and membrane filtration. Disinfection and DNA degradation of community based and hospital wastewater may be effective means to reduce AMR release, although more research is required to fully assess the inactivation of resistance genes (i.e., DNA released from lysed cells that may be available for horizontal gene transfer) by these measures (Dodd, 2012). The combined removal of pollutants that are potential selective agents, disinfection, and deactivation of the genetic material, may be a useful strategy to reduce the pollution of environments with resistance factors.

\section{CONCLUSIONS}

Inevitably, AMR in medicine has become common place. Bacteria have evolved multiple mechanisms for the efficient evolution and spread of AMR. Meanwhile the new developments of quick and adequate molecular diagnostic techniques for the identification and epidemiological surveillance of genetic determinants of AMR in different hosts and in the environment will enhance the number of control options. We have outlined above a number of potential measures that are enabled by our improved ability to track AMR. However, there seems to be a clear need for action and policy changes. This includes drug licensing, financial incentives, penalties, and ban or restriction on use of certain drugs. Similarly, the prescriber behavior needs to be altered. Animal health and hygiene needs to be improved. In addition, the implementation of microbiological criteria for the detection of certain types of resistant pathogens would be important to control the trade of both food animals and food products. The problem of AMR in human medicine will not be solved if nothing is done to limit the constant influx of resistance genes into the human microbiota via the food chain or contact with the environment. Introduction of antimicrobial compounds into the aquatic environment via medical therapy, agriculture, animal husbandry and companion animals has resulted in selective pressures on resident environmental bacteria. Development of AMR in environmental bacteria has a great impact and may help in explaining how human and animal pathogens acquire resistance features. Besides the role of clinical microbiology laboratories with rapid and accurate detection of a diverse number of pathogens and its drug resistance profiles, robust routine surveillances in an epidemiological frame-work covering the whole livestock "food chain" and the environment need to be taken into consideration. Due to this complexity the control of AMR has to include numerous actions at diverse levels. Future research should focus on finding unknown routes of transfer of AMR between microbiotas of relevance to the food chain and to all microbiotas of importance for bacterial pathogens when they acquire antibiotic resistance genes laterally. Ultimately, even a successful integrative approach on all aspects, can probably only help to slow down the spread of AMR, not prevent it. The development of new generations of antimicrobial should therefore receive equal attention. This is summarized and emphasized in a 12-point action plan against the rising threats of AMR implemented by the European Commission which includes actions in the field of human medicine, animal husbandry, veterinary medicine, authorization requirements for commercialization of human and veterinary drugs and other products, on research, on scientific opinions, and undertaking also actions on the international level in collaboration with the WHO and Codex (http://ec.europa.eu/dgs/health_ consumer/does/communication_amr_2011_748_en.pdf, Bush et al., 2011).

The problem of AMR is widespread all over the world, therefore it is not eradicable, but can be managed. Concerted efforts between medical doctors, dentists, veterinarians, scientists, funders, industry, regulators, and multi-disciplinary approaches are needed to track resistance. Furthermore, global monitoring of the antimicrobial drug consumption in human and veterinary medicine and AMR, is an essential part of an overall strategy to inform, educate and get commitment of all parties, including farmers and patients (American Academy of Microbiology, 2009). All these are important measures for the efficient future use of antimicrobials in medicine. All members of society should be conscious of their role and take on responsibility for maintaining the effectiveness of current and future antimicrobials. We believe that future interventions can be successful in minimizing this problem.

\section{AUTHOR CONTRIBUTIONS}

L. Cantas defined the review theme, established the interdisciplinary coordination and the collaborations, designed the manuscript, contributed to the data collection, data analysis, and drafting and writing of the manuscript. Syed Q. A. Shah, L. M. Cavaco, C. M. Manaia, F. Walsh, M. Popowska: drafting, writing, and editing the manuscript. H. Garelick and $\mathrm{H}$. Bürgmann: contributed to data analysis, drafting, and writing the manuscript. H. Sørum: contributed to manuscript design, data collection, data analysis, drafting, and writing the manuscript. All authors have contributed to, seen and approved the manuscript. 
ACKNOWLEDGMENTS AND FUNDING

\section{ลㄷㄷヒ \\ European \\ SCIENCE ESF provides the COST Office through an EC contract}

COST is supported by the EU RTD Framework programme

All authors acknowledge DARE TD0803 (Detecting Antimicrobial Resistance in Europe) COST Action. (http:// www.cost-dare.eu/). This publication is supported by COST. Neither the COST Office nor any person acting on its behalf is responsible for the use which might be made of the information contained in this publication. The COST Office is not responsible for the external websites referred to in this publication. C. M. Manaia acknowledges National Funds from FCTFundação para a Ciência e a Tecnologia through projects PEstOE/EQB/LA0016/2011 and PTDC/AAC-AMB/113840/2009. F. Walsh acknowledges funding from the Swiss Federal Office for Agriculture, the Swiss Federal Office for the Environment and the Swiss Expert Committee for Biosafety (SECB). Finally L. Cantas extend his thanks to MegaVet.no, for helpful support in reviewing the manuscript.

\section{REFERENCES}

Aarestrup, F. M. (2005). Veterinary drug usage and antimicrobial resistance in bacteria of animal origin. Basic Clin. Pharmacol. Toxicol. 96, 271-281.

Aarestrup, F. M., Seyfarth, A. M., Emborg, H. D., Pedersen, K., Hendriksen, R. S., and Bager, F. (2001). Effect of abolishment of the use of antimicrobial agents for growth promotion on occurrence of antimicrobial resistance in fecal Enterococci from food animals in Denmark. Antimicrob. Agents Chemother. 45, 2054-2059.

Abraham, E. P., and Chain, E. (1940). An enzyme from bacteria able to destroy penicillin. Nature 146, 837.

Agersø, Y., and Petersen, A. (2007). The tetracycline resistance determinant Tet 39 and the sulphonamide resistance gene sulII are common among resistant Acinetobacter spp. isolated from integrated fish farms in Thailand. J. Antimicrob. Chemother. 59, 23-27.

Alanis, A. J. (2005). Resistance to antibiotics: are we in the postantibiotic era? Arch. Med. Res. 36, 697-705.

Alexander, T. W., Yanke, J. L., Reuter, T., Topp, E., Read, R. R., Selinger, B. L., et al. (2011). Longitudinal characterization of antimicrobial resistance genes in feces shed from cattle fed different subtherapeutic antibiotics. BMC Microbiol. 11:19. doi: 10.1186/1471-2180-11-19.

Allen, H. K., Donato, J., Wang, H. H., Cloud-Hansen, K. A., Davies, J., and Handelsman, J. (2010). Call of the wild: antibiotic resistance genes in natural environments. Nat. Rev. Microbiol. 8, 251-259.

American Academy of Microbiology. (2009). "Antibiotic resistance: an ecological perspective on an old problem," in Report of a colloquium, 12 to 14 October 2008 (Annecy, France).

Aminov, R., and Mackie, R. I. (2007). Evolution and ecology of antibiotic resistance genes. FEMS Microbiol. Lett. 271, 147-161.

Anderson, A. D., Nelson, J. M., Rossiter, S., and Angulo, F. J. (2003). Public health consequences of use of antimicrobial agents in food animals in the United States. Microb. Drug Resist. 9, 373-379.

Angulo, F. J., Nargund, V. N., and Chiller, T. C. (2004). Evidence of an association between use of anti-microbial agents in food animals and anti-microbial resistance among bacteria isolated from humans and the human health consequences of such resistance. J. Vet. Med. B 51, 374-379.

Anthony, F., Acar, J., Franklin, A., Gupta, R., Nicholls, T., Tamura, Y., et al. (2001). Antimicrobial resistance: responsible and prudent use of antimicrobial agents in veterinary medicine. Rev. Sci. Tech. 20, 829-839.

Arya, S. C., and Agarwal, N. (2011). International travel with acquisition of multi-drug resistant Gram negative bacteria containing the New Delhi metallo-beta-lactamase gene, bla(NDM-1). Travel Med. Infect. Dis. 9, 47-48.

Ash, R. J., Mauck, B., and Morgan, M. (2002). Antibiotic resistance of gram-negative bacteria in rivers, United States. Emerg. Infect. Dis. 8, 713-716.

Baltz, R. H. (2007). Antimicrobials from actinomycetes: back to the future. Microbe 2, 125-131.

Bannoehr, J., Ben Zakour, N. L., Waller, A. S., Guardabassi, L., Thoday, K. L., van den Broek, A. H., et al. (2007). Population genetic structure of the Staphylococcus intermedius group: insights into agr diversification and the emergence of methicillinresistant strains. J. Bacteriol. 189, 8685-8692.

Baquero, F., Alvarez-Ortega, C., and Martinez, J. L. (2009). Ecology and evolution of antibiotic resistance. Environ. Microbiol. Rep. 1, 469-476.
Baquero, F., Martinez, J.-L., and Canton, R. (2008). Antibiotics and antibiotic resistance in water environments. Curr. Opin. Biotechnol. 19, 260-265.

Barber, M., and RozwadowskaDowzenko, M. (1948). Infection by penecillin-resistant staphylococci. Lancet 2, 641-644.

Bastianello, S. S., Fourie, N., Prozesky, L., Nel, P. W., and Kellermann, T. S. (1995). Cardiomyopathy of ruminants induced by the litter of poultry fed on rations containing the ionophore antibiotic, maduramicin.2. macropathology and histopathology. Onderstepoort J. Vet. Res. 62, 5-18.

Björklund, H. V., Råbergh, C. M. I., and Bylund, G. (1991). Residues of oxolinic acid and oxytetracycline in fish and sediments from fish farms. Aquaculture 97, 85-96.

Blanch, A. R., Caplin, J. L., Iversen, A., Kühn, I., Manero, A., Taylor, H. D., et al. (2003). Comparison of enterococcal populations related to urban and hospital wastewater in various climatic and geographic European regions. J. Appl. Microbiol. 94, 994-1002.

Böckelmann, U., Dorries, H. H., Ayuso-Gabella, M. N., Marçay, M. S., Tandoi, V., Levantesi, C., et al. (2009). Quantitative PCR monitoring of antibiotic resistance genes and bacterial pathogens in three European artificial groundwater recharge systems. J. Appl. Environ. Microbiol. 75, 154-163.

Brown, S., Bantar, C., Young, H. K., and Amyes, S. G. B. (1998). Limitation of Acinetobacter baumannii treatment by plasmid-mediated carbapenemase ARI-2. Lancet 351, 186-187.

Bush, K., Courvalin, P., Dantas, G., Davies, J., Eisenstein, B., Huovinen, P., et al. (2011). Tackling antibiotic resistance. Nat. Rev. Microbiol. 9, 894-896.

Cabello, F. C. (2006). Heavy use of prophylactic antibiotics in aquaculture: a growing problem for human and animal health and for the environment. Environ. Microbiol. 8, 1137-1144.

Callaway, T. R., Edrington, T. S. Anderson, R. C., Harvey, R. B., Genovese, K. J., Kennedy, C. N., et al. (2008). Probiotics, prebiotics and competitive exclusion for prophylaxis against bacterial disease. Anim. Health Res. Rev. 9, 217-225.

Cantas, L., Fraser, T. W. K., Fjelldal, P. G., Mayer, I., and Sørum, H. (2011). The culturable intestinal microbiota of triploid and diploid juvenile Atlantic salmon (Salmo salar) _ a comparison of composition and drug resistance. BMC Vet. Res. 7:71. doi: 10.1186/1746-6148-7-71

Cantas, L., Le Roux, F., Mazel, D., and Sørum, H. (2012a). Impact of Antibiotics on the Expression of the tra Genes and on the Host Innate Immune Gene Activity during SXT Element Bearing Aeromonas salmonicida Infection in Atlantic Salmon (Salmo salar L.). PSN-ICAAC12PS1-B-1330. San Francisco, CA.

Cantas, L., Torp, J. R., Alestrøm, P., Sørum, H. (2012b). Cultureable gut microbiota diversity in zebrafish. Zebrafish 9, 26-37.

Cantas, L., Midtlyng, P. J., and Sørum, H. (2012c). Impact of antibiotic treatments on the expression of the $\mathrm{R}$ plasmid tra genes and on the host innate immune activity during pRAS1 bearing Aeromonas hydrophila infection in zebrafish (Danio rerio). BMC Microbiol. 12:37. doi: 10.1186/1471-2180-12-37

Cantas, L., Thoresen, I. S., Gjermund, G., Sivertsen, T., Framstad, T., and Sørum, H. (2013). "Antibiotikabehandling av kolidiaré hos spedgris med minimal antibiotikaresistensutviklingen modellstudie (in Norwegian)," in Husdyrforsøksmøte 2013 - UMB (Lillestrøm). 
Caprioli, A., Busani, L., Martel, J. L., and Helmuth, R. (2000). Monitoring of antibiotic resistance in bacteria of animal origin: epidemiological and microbiological methodologies. Int. J. Antimicrob. Agents 14, 295-301.

Casewell, M., Friis, C., Marco, E., McMullin, P., and Phillips, I. (2003). The European ban on growth-promoting antibiotics and emerging consequences for human and animal health. J. Antimicrob. Chemother. 52, 159-161.

Cattoir, V., Poirel, L., Mazel, D., Soussy, C. J., and Nordmann, P. (2007). Vibrio splendidus as the source of plasmid-mediated qnrS-Like quinolone resistance determinants. Antimicrob. Agents Chemother. 51, 2650-2651.

Cheng, A. C., Turnidge, J., Collignon, P., Looke, D., Barton, M., and Gottlieb, T. (2012). Control of fluoroquinolone resistance through successful regulation, Australia. Emerg. Infect. Dis. 18, 1453-1460.

Colquhoun, D. J., Aarflot, L., and Melvold, C. F. (2007). gyrA and parC mutations and associated quinolone resistance in Vibrio anguillarum serotype $\mathrm{O} 2 \mathrm{~b}$ strains isolated from farmed Atlantic cod (Gadus morhua) in Norway. Antimicrob. Agents Chemother. 51, 2597-2599.

Corpet, D. E. (1988). Antibiotic resistance from food. N. Engl. J. Med. 318, 1206-1207.

Crofton, J., and Mitchison, D. A. (1948). Streptomycin resistance in pulmonary tuberculosis. $\mathrm{Br}$. Med. J. 2, 1009-1015.

Cunha, B. A. (2002). Strategies to control antibiotic resistance. Semin. Respir. Infect. 17, 250-258.

Cuny, C., Friedrich, A., Kozytska, S., Layer, F., Nubel, U., Ohlsen, K., et al. (2010). Emergence of methicillin-resistant Staphylococcus aureus (MRSA) in different animal species. Int. J. Med. Microbiol. 300, 109-117.

Czekalski, N., Berthold, T., Caucci, S., Egli, A., and Burgmann, H. (2012). Increased levels of multiresistant bacteria and resistance genes after wastewater treatment and their dissemination into Lake Geneva, Switzerland. Front. Microbiol. 3:106. doi: 10.3389/fmicb.2012.00106

D'Costa, V. M., King, C. E., Kalan, L., Morar, M., Sung, W. W. L., Schwarz, C., et al. (2011). Antibiotic resistance is ancient. Nature 477, 457-461.

D'Costa, V. M., McGrann, K. M., Hughes, D. W., and Wright, G. D. (2006). Sampling the antibiotic resistome. Science 311, 374-377.

Decousser, J. W., Poirel, L., and Nordmann, P. (2001). Characterization of a chromosomally encoded extended-spectrum class A $\beta$-lactamase from Kluyvera cryocrescens. Antimicrob. Agents Chemother. 45, 3595-3598.

Defoirdt, T., Sorgeloos, P., and Bossier, P. (2011). Alternatives to antibiotics for the control of bacterial disease in aquaculture. Curr. Opin. Microbiol. $14,251-258$.

Dodd, M. C. (2012). Potential impacts of disinfection processes on elimination and deactivation of antibiotic resistance genes during water and wastewater treatment. J. Environ. Monit. 14, 1754-1771.

Derewacz, D. K., Goodwin, C. R., McNees, C. R., McLean, J. A., and Bachmann, B. O. (2013). Antimicrobial drug resistance affects broad changes in metabolomic phenotype in addition to secondary metabolism. Proc. Natl. Acad. Sci. U.S.A. 110, 2336-2341.

FAAIR Scientific. (2002). Select findings and conclusions. Clin. Infect. Dis. 34, S73-S75.

Falagas, M. E., and Bliziotis, I. A. (2007). Pandrug-resistant Gramnegative bacteria: the dawn of the post-antibiotic era? Int. J. Antimicrob. Agents 29, 630-636.

Falcone-Dias, M. F., Vaz-Moreira, I., and Manaia, C. M. (2012). Bottled mineral water as a potential source of antibiotic resistant bacteria. Water Res. 46, 3612-3622.

FAO. (2010). The State of the World Fisheries and Aquaculture. Rome: United Nations Food and Agriculture Organization.

Farmed Fish Health Report. (2010). "Norwegian Veterinary Institute," in The Health Situation in Norwegian Aquaculture 2010, eds G. Bornø and C. Sviland (Oslo: Norwegian Veterinary Institute).

Ferreira da Silva, M., Tiago, I., Verissimo, A., Boaventura, R. A. R., Nunes, O. C., and Manaia, C. M. (2006). Antibiotic resistance of enterococci and related bacteria in an urban wastewater treatment plant. FEMS Microbiol. Ecol. 55, 322-329.

Ferreira da Silva, M., Vaz-Moreira, I., Gonzalez-Pajuelo, M., Nunes, O. C., and Manaia, C. M. (2007). Antimicrobial resistance patterns in Enterobacteriaceae isolated from an urban wastewater treatment plant. FEMS Microbiol. Ecol. 60, 166-176.

Filice, G. A., Nyman, J. A., Lexau, C., Lees, C. H., Bockstedt, L. A.,
Como-Sabetti, K., et al. (2010). Excess costs and utilization associated with methicillin resistance for patients with Staphylococcus aureus infection. Infect. Control Hosp. Epidemiol. 31, 365-373.

Fischer, J., Rodriguez, I., Schmoger, S., Friese, A., Roesler, U., Helmuth, R., et al. (2012). Escherichia coli producing VIM-1 carbapenemase isolated on a pig farm. J. Antimicrob. Chemother. 67, 1793-1795.

Forsberg, K. J., Reyes, A., Wang, B., Selleck, E. M., Sommer, M. O. A., and Dantas, G. (2012). The shared antibiotic resistome of soil bacteria and human pathogens. Science 337, 1107-1111.

Giguêre, S., Prescott, J. F., Baggot, J. D., Walker, R. D., and Dowling, P. M. (2007). Antimicrobial Therapy in Veterinary Medicine. Ames; Oxford: Iowa State University Press.

Glad, T.,Bernhardsen, P.,Nielsen, K. M., Brusetti, L., Andersen, M., Aars, J., et al. (2010). Bacterial diversity in faeces from polar bear (Ursus maritimus) in Arctic Svalbard. BMC Microbiol. 10:10. doi: 10.1186/ 1471-2180-10-10

Goñi-Urriza, M., Capdepuy, M., Arpin, C., Raymond, N., Caumette, P., and Quentin, C. (2000). Impact of an urban effluent on antibiotic resistance of riverine Enterobacteriaceae and Aeromonas spp. J. Appl. Environ. Microb. 66, 125-132.

Götz, A., Pukall, R., Smit, E., Tietze, E., Prager, R., Tschäpe, H., et al. (1996). Detection and characterization of broad-host range plasmids in environmental bacteria by PCR. Appl. Environ. Microbiol. 62, 2621-2628.

Graham, D. W., Olivares-Rieumont, S., Knapp, C. W., Lima, L., Werner, D., and Bowen, E. (2011). Antibiotic resistance gene abundances associated with waste discharges to the Almendares River near Havana, Cuba. Environ. Sci. Technol. 45, 418-424.

Gräslund, S., Holmström, K., and Wahlström, A. (2003). A field survey of chemicals and biological products used in shrimp farming. Mar. Pollut. Bull. 46, 81-90.

Grave, K., Torren-Edo, J., and Mackay, D. (2010). Comparison of the sales of veterinary antibacterial agents between 10 European countries. J. Antimicrob. Chemother. 65, 2037-2040.

Gullberg, E., Cao, S., Berg, O. G., Ilback, C., Sandegren, L., Hughes, D., et al. (2011). Selection of resistant bacteria at very low antibiotic concentrations. PLoS Pathog. 7:e1002158. doi: 10.1371/journal.ppat.1002158
Gustafson, R. H., and Bowen, R. E. (1997). Antibiotic use in animal agriculture. J. Appl. Microbiol. 83, 531-541.

Halverson, M. (2000). The Price We Pay for Corporate Hogs. Minneapolis, MN: Institute for Agriculture and Trade policy, 32 .

Hammerum, A. M., Heuer, O. E., Emborg, H. D., Bagger-Skjot, L., Jensen, V. F., Rogues, A. M., et al. (2007). Danish integrated antimicrobial in resistance monitoring and research program. Emerg. Infect. Dis. 13, 1632-1639.

Hektoen, H., Berge, J. A., Hormazabal, V., and Yndestad, M. (1995). Persistence of antibacterial agents in marine sediments. Aquaculture 133, 175-184.

Heuer, O. E., Kruse, H., Grave, K., Collignon, P., Karunasagar, I., and Angulo, F. J. (2009). Human health consequences of use of antimicrobial agents in aquaculture. Clin. Infect. Dis. 49, 1248-1253.

Hoa, P. T. P., Managaki, S., Nakada, N., Takada, H., Shimizu, A., Anh, D. H. et al. (2011). Antibiotic contamination and occurrence of antibioticresistant bacteria in aquatic environments of northern Vietnam. Sci. Total Environ. 409, 2894-2901.

Holmberg, S. D., Solomon, S. L., and Blake, P. A. (1987). Health and economic impacts of antimicrobial resistance. Rev. Infect. Dis. 9, 1065-1078.

Holmström, K., Gräslund, S., Wahlström, A., Poungshompoo, S. Bengtsson, B. E., and Kautsky, N. (2003). Antibiotic use in shrimp farming and implications for environmental impacts and human health. Int. J. Food Sci. Technol. 38, 255-266.

Horton, R. A., Randall, L. P., Snary, E. L., Cockrem, H., Lotz, S., Wearing, H., et al. (2011). Fecal carriage and shedding density of CTX$\mathrm{M}$ extended-spectrum $\beta$-lactamaseproducing Escherichia coli in cattle, chickens, and pigs: implications for environmental contamination and food production. Appl. Environ. Microbiol. 77, 3715-3719.

Jean-Louis, M., Tardy, F., Brisabois, A., Lailler, R., Coudert, M., ChaslusDancla, E. (2000). The French antibiotic resistance monitoring programs. Int. J. Antimicrob. Agents 14, 275-283.

Klugman, K. P. (2002). Bacteriological evidence of antibiotic failure in pneumococcal lower respiratory tract infections. Eur. Respir. J. 20, 3S-8S.

Kluytmans, J. A. J. W. (2010). Methicillin-resistant Staphylococcus 
aureus in food products: cause for concern or case for complacency? Clin. Microbiol. Infect. 16, 11-15.

Knapp, C. W., Dolfing, J., Ehlert, P. A., and Graham, D. W. (2010). Evidence of increasing antibiotic resistance gene abundances in archived soils since 1940. Environ. Sci. Technol. 44, 580-587.

Knapp, C. W., Engemann, C. A., Hanson, M. L., Keen, P. L., Hall, K. J., and Graham, D. W. (2008). Indirect evidence of transposon-mediated selection of antibiotic resistance genes in aquatic systems at low-level oxytetracycline exposures. Environ. Sci. Technol. 42, 5348-5353.

Kohanski, M. A., DePristo, M. A., and Collins, J. J. (2010). Sublethal antibiotic treatment leads to multidrug resistance via radicalinduced mutagenesis. Mol. Cell 37, 311-320.

Korczak, D., and Schöffmann, C. (2010). Medical and health economic evaluation of preventionand control measures related to MRSA infections or -colonisations at hospitals. GMS Health Technol. Assess. 6, 1-9.

Kumarasamy, K. K., Toleman, M. A., Walsh, T. R., Bagaria, J., Butt, F., Balakrishnan, R., et al. (2010). Emergence of a new antibiotic resistance mechanism in India, Pakistan, and UK: a molecular, biological, and epidemiological study. Lancet Infect. Dis. 10, 597-602.

Lang, K. S., Anderson, J. M., Schwarz, S., Williamson, L., Handelsman, J., and Singer, R. S. (2010). Novel florfenicol and chloramphenicol resistance gene discovered in Alaskan soil by using functional metagenomics. Appl. Environ. Microbiol. 76, 5321-5326

Levy, S. B. (1984). "Antibiotic resistant bacteria in food of man and animals," in Antimicrobials Ans Agriculture, ed M. Woodbine (London: Butterworths), 525-531.

Levy, S. B. (1998). The challange of antibiotic resistance. Sci. Am. 278, 46-53.

Levy, S. B. (2001). Antibiotic resistance: consequences of inaction. Clin. Infect. Dis. 33, 124-129.

Levy, S. B., FitzGerald, G. B., and Macone, A. B. (1976). Changes in intestinal flora of farm personnel after introduction of a tetracyclinesupplemented feed on a farm. $N$. Engl. J. Med. 295, 583-588.

Levy, S. B., and Marshall, B. (2004). Antibacterial resistance worldwide: causes, challenges and responses. Nat. Med. 10, 122-129.
Lie, Ø. (2008). Improving Farmed Fish Quality and Safety. Woodhead, Publishing Series in Food Science, Technology and Nutrition No. 162. E-ISBN: 978-1-84569-492-0.

Linton, K. B., Lee, P. A., Rowland, A. J., Baker, V. N., Gillespi, W. A., and Richmond, M. H. (1972). Antibiotic resistance and transmissible R-factors in intestinal Coliform flora of healthy adults and children in an urban and a rural community. J. Hyg. (Lond.) 70 99-104.

Literak, I., Petro, R., Dolejska, M., Gruberova, E., Dobiasova, H., Petr, J., et al. (2011). Antimicrobial resistance in fecal Escherichia coli isolates from healthy urban children of two age groups in relation to their antibiotic therapy. Antimicrob. Agents Chemother. 55, 3005-3007.

Ma, J., Liu, J. H., Lv, L., Zong, Z., Sun, Y., Zheng, H., et al. (2012). Characterization of extendedspectrum $\beta$-lactamase genes among Escherichia coli isolates from duck and environment samples in a duck farm. Appl. Environ. Microbiol. 78, 3668-3673.

Markestad, A., and Grave, K. (1997). Reduction of antibacterial drug use in Norwegian fish farming due to vaccination. Dev. Biol. Stand. 90, 365-369.

Marshall, B., Petrowski, D., and Levy, S. B. (1990). Inter- and intraspecies spread of Escherichia coli in a farm environment in the absence of antibiotic usage. Proc. Natl. Acad. Sci. U.S.A. 87, 6609-6613.

Marshall, B. M., and Levy, S. B. (2011). Food animals and antimicrobials: impacts on human health. Clin. Microbiol. Rev. 24, 718-733.

Martinez, J. L. (2009). Environmental pollution by antibiotics and by antibiotic resistance determinants. Environ. Pollut. 157, 2893-2902.

McEwen, S. A. (2006). Antibiotic use in animal agriculture: what have we learned and where are we going? Anim. Biotechnol. 17, 239-250.

McManus, P. S., Stockwell, V. O., Sundin, G. W., and Jones, A. L. (2002). Antibiotic use in plant agriculture. Annu. Rev. Phytopathol. 40, 443-465.

Michael, I., Rizzo, L., McArdell, C. S., Manaia, C. M., Merlin, C., Schwartz, T., et al. (2013). Urban wastewater treatment plants as hotspots for the release of antibiotics in the environment: a review. Water Res. 47 957-995.

Midtlyng, P. J., Grave, K., and Horsberg, T. E. (2011). What has been done to minimize the use of antibacterial and antiparasitic drugs in
Norwegian aquaculture. Aquac. Res. 42, 28-34.

Moura, A., Henriques, I., Smalla, K. and Correia, A. (2010). Wastewater bacterial communities bring together broad-host range plasmids, integrons and a wide diversity of uncharacterized gene cassettes. Res. Microbiol. 161, 58-66.

Muto, C. A., Jernigan, J. A., Ostrowsky, B. E., Richet, H. M., Jarvis, W. R., Boyce, J. M., et al. (2003). SHEA guideline for preventing nosocomial transmission of multidrugresistant strains of Staphylococcus aureus and Enterococcus. Infect. Control Hosp. Epidemiol. 24, 362-386.

Ndi, O., and Barton, M. (2012) "Antibiotic resistance in animalsThe Australian perspective," in Antimicrobial Resistance in the Environment, eds P. L. Keen and M. H. H. M. Montforts (New Jersey, NJ: Wiley-Blackwell), 265-290.

Nkogwe, C., Raletobana, J., StewartJohnson, A., Suepaul, S., and Adesiyun, A. (2011). Frequency of detection of Escherichia coli, Salmonella spp., and Campylobacter spp. in the faeces of wild rats (Rattus spp.) in Trinidad and Tobago. Vet. Med. Int. 2011:686923. doi: 10.4061/ 2011/686923

Nordmann, P., Dortet, L., and Poirel, L. (2012). Carbapenem resistance in Enterobacteriaceae: here is the storm! Trends Mol. Med. 18, 263-272.

Nordmann, P., Poirel, L., Toleman, M. A., and Walsh, T. R. (2011). Does broad-spectrum $\beta$-lactam resistance due to NDM-1 herald the end of the antibiotic era for treatment of infections caused by Gram-negative bacteria? J. Antimicrob. Chemother. 66, 689-692.

NORM/NORM-VET. (2011). Usage of Antimicrobial Agents and Occurrence of Antimicrobial Resistance in Norway. Tromsø/Oslo 2012. ISSN:1502-2307 (print)/18909965 (electronic). (Tromsø/Oslo: Norwegian Veterinary Institute). Available online at: http://www. vetinst.no/eng/Publications/NormNorm-Vet-Report/Norm-Norm-Vetrapporten-2010

Novo, A., André, S., Viana, P., Nunes, O. C., and Manaia, C. M. (2013) Antibiotic resistance, antimicrobial residues and bacterial community composition in urban wastewater. Water Res. 47, 1875-1887.

Novo, A., and Manaia, C. M. (2010). Factors influencing antibiotic resistance burden in municipal wastewater treatment plants.
Appl. Microbiol. Biotechnol. 87, 1157-1166.

Oberlé, K., Capdeville, M., Berthe, T., and Petit, F. (2012). Evidence for a complex relationship between antibiotics and antibiotic-resistant Escherichia coli: from medical center patients to a receiving environment. Environ. Sci. Technol. 46, 1859-1868

Olarte, J. (1983). Antibiotic resistance in Mexico. APUA Newslett. 1, 3.

Olliver, A., Vallê, M., Chaslus-Dancla, E., and Cloeckaert, A. (2005). Overexpression of the multidrug efflux operon acrEF by insertional activation with IS1 or IS10 elements in Salmonella enterica Serovar Typhimurium DT204 acrB mutants selected with fluoroquinolones. Antimicrob. Agents Chemother. 49, 289-301.

Otter, J. A., and French, G. L. (2010). Molecular epidemiology of community-associated meticillin-resistant Staphylococcus aureus in Europe. Lancet Infect. Dis. 10, 227-239.

Pallett, A., and Hand, K. (2010). Complicated urinary tract infections: practical solutions for the treatment of multiresistant Gramnegative bacteria. J. Antimicrob. Chemother. 65, 25-33.

Patra, S., Das, T. K., Avila, C., Cabello, V., Castillio, F., Sarkar, D., et al. (2012). Cadmium tolerance and antibiotic resistance in Escherichia coli isolated from waste stabilization ponds. Indian J. Exp. Biol. 50 300-307.

Petersen, A., Andersen, J. S., Kaewmak, T., Somsiri, T., and Dalsgaard, A. (2002). Impact of integrated fish farming on antimicrobial resistance in a pond environment. Appl. Environ. Microbiol. 68, 6036-6042.

Picao, R. C., Poirel, L., Demarta, A., Silva, C. S. F., Corvaglia, A. R., Petrini, O., et al. (2008). Plasmidmediated quinolone resistance in Aeromonas allosaccharophila recovered from a Swiss lake. J. Antimicrob. Chemother. 62, 948-950.

Poirel, L., Liard, A., RodriguezMartinez, J. M., and Nordmann, P. (2005). Vibrionaceae as a possible source of Qnr-like quinolone resistance determinants. J. Antimicrob. Chemother. 56, 1118-1121.

Popowska, M., and Krawczyk-Balska, A. (2013). Broad-Host-Range IncP1 plasmids and their resistance potential. Front. Microbiol. 4:44. doi: 10.3389/fmicb.2013.00044

Popowska, M., Miernik, A., Rzeczycka, M., and Lopaciuk, A. (2010). The impact of environmental 
contamination with antibiotics on levels of resistance in soil bacteria. J. Environ. Qual. 39, 1679-1687.

Popowska, M., Rzeczycka, M., Miernik, A., Krawczyk-balska, A., Walsh, F., and Duffy, B. (2012). Influence of soil use on prevalence of tetracycline, streptomycin, and erythromycin resistance and associated resistance genes. Antimicrob. Agents Chemother. 56, 1434-1443.

Potter, A., Gerdts, V., and Littel-Van den Hurk, S. V. (2008). Veterinary vaccines: alternatives to antibiotics? Anim. Health Res. Rev. 9, 187-199.

Pouillard, J. (2002). A forgotten discovery: doctor of medicine Ernest Duchesne, s thesis (1874-1912) [Article in French]. Hist. Sci. Med. $36,11-20$.

Pratt, R. (2010). Preparation for a post antibiotic era must start now. Nurs. Times 106, 26.

Primavera, J. H. (2006). Overcoming the impacts of aquaculture on the coastal zone. Ocean Coast. Manage. 49, 531-545.

Pruden, A., Arabi, M., and Storteboom, H. N. (2012). Correlation between upstream human activities and riverine antibiotic resistance genes. Environ. Sci. Technol. 46, 11541-11549.

Rassow, D., and Schaper, H. (1996). The use of feed medications in swine and poultry facilities in the Weser-Ems region [Article in German]. Dtsch. Tierarztl. Wochenschr. 103, 244-249.

Reinthaler, F. F., Posch, J., Feierl, G., Wüst, G., Haas, D., Ruckenbauer, G., et al. (2003). Antibiotic resistance of E. coli in sewage and sludge. Water Res. 37, 1685-1690.

Rhodes, G., Huys, G., Swings, J., McGann, P., Hiney, M., Smith, P., et al. (2000). Distribution of oxytetracycline resistance plasmids between Aeromonads in hospital and aquaculture environments: implication of Tn1721 in dissemination of the tetracycline resistance determinant Tet, A. Appl. Environ. Microbiol. 66, 3883-3890.

Riesenfeld, C. S., Goodman, R. M., and Handelsman, J. (2004a). Uncultured soil bacteria are a reservoir of new antibiotic resistance genes. Environ. Microbiol. 6, 981-989.

Riesenfeld, C. S., Schloss, P. D., and Handelsman, J. (2004b). Metagenomics: genomic analysis of microbial communities. Annu. Rev. Genet. 38, 525-552.

Rizzo, L., Manaia, C. M., Merlin, C., Schwartz, T., Dagot, D., Ploy, M. C., et al. (2013). Urban wastewater treatment plants as hotspots for antibiotic resistant bacteria and genes spread into the environment: a review. Sci. Total Environ. 447, 345-360.

Roberts, R. R., Hota, B., Ahmad, I. Scott, R. D., Foster, S. D., Abbasi, F., et al. (2009). Hospital and societal costs of antimicrobial-resistant infections in a Chicago teaching hospital: implications for antibiotic stewardship. Clin. Infect. Dis. 49, 1175-1184.

Rodriguez, M. M., Power, P., Radice, M., Vay, C., Famiglietti, A., Galleni, M., et al. (2004). Chromosomeencoded CTX-M-3 from Kluyvera ascorbata: a possible origin of plasmid-borne CTX-M-1-derived cefotaximases. Antimicrob. Agents Chemother. 48, 4895-4897.

Roe, M. T., and Pillai, S. D. (2003). Monitoring and identifying antibiotic resistance mechanisms in bacteria. Poult. Sci. 82, 622-626.

Roura, E., Homedes, J., and Klasing, K. C. (1992). Prevention of immunologic stress contributes to the growth-permitting ability of dietary antibiotics in chicks. J. Nutr. 122, 2383-2390.

Sato, K., Bartlett, P. C., and Saeed, M. A. (2005). Antimicrobial susceptibility of Escherichia coli isolates from dairy farms using organic versus conventional production methods. J. Am. Vet. Med. Assoc. 226, 589-594.

Schwartz, T., Volkmann, H., Kirchen, S., Kohnen, W., Schön-Hölz, K. Jansen, B., et al. (2006). Realtime PCR detection of Pseudomonas aeruginosa in clinical and municipal wastewater and genotyping of the ciprofloxacin-resistant isolates. FEMS Microbiol. Ecol. 57, 158-167.

Segura, P. A., Francois, M., Gagnon, C., and Sauve, S. (2009). Review of the occurrence of anti-infectives in contaminated wastewaters and natural and drinking waters. Environ. Health Perspect. 117, 675-684.

Seiler, C., and Berendonk, T. U. (2012). Heavy metal driven co-selection of antibiotic resistance in soil and water bodies impacted by agriculture and aquaculture. Front. Microbiol. doi: 10.3389/fmicb.2012.00399

Sen, D., Van Der Auwera, G., Rogers, L., Thomas, C. M., Brown, C. J., and Top, E. M. (2011). Broadhost-range plasmids from agricultural soils have IncP-1 backbones with diverse accessory genes. Appl. Environ. Microbiol. 77, 7975-7983.

Serrano, P. H. (2005). "Responsible use of antibiotics in aquaculture," in FAO Fisheries technical paper 469 (Rome; United Nations), 89 Available online at: ftp://ftp.fao.org/ docrep/fao/009/a0282e/a0282e00. pdf

Shah, S. Q. A., Karatas, S., Nilsen, H., Steinum, T. M., Colquhoun, D. J., and Sørum, H. (2012a). Characterization and expression of the gyrA gene from quinolone resistant Yersinia ruckeri strains isolated from Atlantic salmon (Salmo salar L.) in Norway. Aquaculture 350-353, 37-41.

Shah, S. Q. A., Colquhoun, D. J., Nikuli, H. L., and Sørum, H. (2012b). Prevalence of antibiotic resistance genes in the bacterial flora of integrated fish farming environments of Pakistan and Tanzania. Environ. Sci. Technol. 46 8672-8679.

Sharma, R., Munns, K., Alexander, T., Entz, T., Mirzaagha, P., Yanke, L. J., et al. (2008). Diversity and distribution of commensal fecal Escherichia coli bacteria in beef cattle administered selected subtherapeutic antimicrobials in a feedlot setting. Appl. Environ. Microbiol. 74 6178-6186.

Shtienberg, D., Zilberstaine, M. Oppenheim, D., Herzog, Z. Manulis, S., Shwartz, H., et al. (2001). Efficacy of oxolinic acid and other bactericides in suppression of Erwinia amylovora in pear orchards in Israel. Phytoparasitica 29, 143-154.

Smith, P. R., Le Breton, A., Horsberg T. E., and Corsin, F. (2009). "Guidelines for antimicrobial use in aquaculture," in Guide to Antimicrobial Use in Animals, eds L. Guardabassi, L. B. Jensen, and H. Kruse (Oxford: Blackwell Publishing Ltd.), 207-218.

Soonthornchaikul, N., Garelick, H., Jones, H., Jacobs, J., Ball, D., and Choudhury, M. (2006). Resistance to three antimicrobial agents of Campylobacter isolated from intensively and organically reared chickens purchased from retail outlets. Int. J. Antimicrob. Agents 27, 125-130.

Soonthornchaikul, N., and Garelick, H. (2009). Antimicrobial resistance of Campylobacter species isolated from edible bivalve molluscs purchased from Bangkok markets, Thailand. Foodborne Pathog. Dis. 6, 947-951.

Sørum, H. (2006). "Antimicrobial drug resistance in fish pathogens," in Antimicrobial Resistance in Bacterio of Animal Origin, ed F. M. Aarestrup (Washington, DC: ASM Press) 213-238.
Sørum, H. (2008). "Antibiotic resistance associated with veterinary drug use in fish farms," in Improving Farmed Fish Quality and Safety, ed ø. Lie (Cambridge: WoodHead Publishing Limit), 157-182.

Stockwell, V. O., and Duffy, B. (2012). Use of antibiotics in plant agriculture. Rev. Sci. Tech. 31, 199-210.

Stokes, H. W., and Gillings, M. R (2011). Gene flow, mobile genetic elements and the recruitment of antibiotic resistance genes into Gram negative pathogens. FEMS Microbiol. Rev. 35, 790-819.

Strahilevitz, J., Jacoby, G., Hooper, D. C., and Robicsek, A. (2009). Plasmid-mediated quinolone resistance: a multifaceted threat. Clin. Microbiol. Rev. 22, 664-689.

Sundin, G. W., Monks, D. E., and Bender, C. L. (1995). Distribution of the streptomycin-resistance transposon Tn5393 among phylloplane and soil bacteria from managed agricultural habitats. Can. J. Microbiol. 41, 792-799.

Swann, M. M. (1969). Use of Antibiotics in Animal Husbandry and Veterinary Medicine (Swann Report). London: HMSO.

Swartz, M. N. (2002). Human diseases caused by foodborne pathogens of animal origin. Clin. Infect. Dis. 34, S111-S122.

Szczepanowski, R. H., Carpenter, M. A., Czapinska, H., Zaremba, M., Tamulaitis, G., Siksnys, V., et al. (2008). Central base pair flipping and discrimination by PspGI. Nucleic Acids Res. 36, 6109-6117.

Szczepanowski, R., Linke, B., Krahn, I., Gartemann, K.-H., Gutzkow, T., Eichler, W., et al. (2009). Detection of 140 clinically relevant antibiotic- resistance genes in the plasmid metagenome of wastewater treatment plant bacteria showing reduced susceptibility to selected antibiotics. Microbiology 155, 2306-2319.

Tablan, O. C., Anderson, L. J., Besser, R., Bridges, C., and Hajjeh, R. (2004). Guidelines for preventing health-care-associated pneumonia, 2003: recommendations of CDC and the Healthcare Infection Control Practices Advisory Committee. MMWR Recomm. Rep. 53, 1-36.

Tennstedt, T., Szczepanowski, R., Braun, S., Puhler, A., and Schluter, A. (2003). Occurrence of integronassociated resistance gene cassettes located on antibiotic resistance plasmids isolated from a wastewater 
treatment plant. FEMS Microbiol. Ecol. 45, 239-252.

Thaker, M., Spanogiannopoulos, P., and Wright, G. D. (2010). The tetracycline resistome. Cell. Mol. Life Sci. 67, 419-431.

Thiele-Bruhn, S. (2003). Pharmaceutical antibiotic compounds in soils-a review. J. Plant Nutr. Soil Sci. 166, 145-167.

Torres-Cortés, G., Millan, V., RamirezSaad, H.C., Nisa-Martinez, R., Toro, N., and Martinez-Abarca, F. (2011). Characterization of novel antibiotic resistance genes identified by functional metagenomics on soil samples. Environ. Microbiol. 13, 1101-1114.

Vaz-Moreira, I., Nunes, O. C., and Manaia, C. M. (2011). Diversity and antibiotic resistance patterns of Sphingomonadaceae isolated from drinking water. Appl. Environ. Microbiol. 77, 5697-5706.

Vazquez-Moreno, L., Bermudez, A., Langure, A., Higuera-Ciapara, I., Diaz De Aguayo, M., and lores, E. (1990). Antibiotic residues and drug resistant bacteria in beef, and chicken tissues. J. Food Sci. 55, 632-634.

Verschuere, L., Rombaut, G., Sorgeloos, P., and Verstraete, W. (2000). Probiotic bacteria as biological control agents in aquaculture. Microbiol. Mol. Biol. Rev. 64, 655-671.

Volkmann, H., Schwartz, T., Bischoff, P., Kirchen, S., and Obst, U. (2004). Detection of clinically relevant antibiotic-resistance genes in municipal wastewater using realtime PCR (TaqMan). J. Microbiol. Methods 56, 277-286.

Walsh, T. R., Weeks, J., Livermore, D. M., and Toleman, M. A. (2011). Dissemination of NDM-1 positive bacteria in the New Delhi environment and its implications for human health: an environmental point prevalence study. Lancet Infect. Dis. 11, 355-362.

Watanabe, T. (1963). Infective heredity of multiple drug resistance in bacteria. Bacteriol. Rev. 27, 87-115.

Watkinson, A. J., Micalizzi, G. R., Bates, J. R., and Costanzo, S. D. (2007). Novel method for rapid assessment of antibiotic resistance in Escherichia coli isolates from environmental waters by use of a modified chromogenic agar. Appl. Environ. Microbiol. 73, 2224-2229.

Weese, J. S. (2010). Methicillin-resistant Staphylococcus aureus in animals. ILAR J. 51, 233-244.

Welch, T. J., Fricke, W. F., McDermott, P. F., White, D. G., Rosso, M. L., Rasko, D. A., et al. (2007). Multiple antimicrobial resistance in plague: an emerging public health risk. PLoS ONE 2:e309. doi 10.1371/journal.pone.0000309

Wieler, L. H., Ewers, C., Guenther, S., Walther, B., and Lübke-Becker, A. (2011). Methicillin-resistant staphylococci (MRS) and extended-spectrum betalactamases (ESBL)-producing Enterobacteriaceae in companion animals: nosocomial infections as one reason for the rising prevalence of these potential zoonotic pathogens in clinical samples. Int. J. Med. Microbiol. 301, 635-641.

Wilke, M. H. (2010). Multiresistant bacteria and current therapy-the economical side of the story. Eur. J. Med. Res. 15, 571-576.

Yang, C., Zhang, W., Liu, R., Li, Q., Li, B., Wang, S., et al. (2011). Phylogenetic diversity and metabolic potential of activated sludge microbial communities in full-scale wastewater treatment plants. Environ. Sci. Technol. 45, 7408-7415.

Ye, L., and Zhang, T. (2011). Pathogenic bacteria in sewage treatment plants as revealed by 454 pyrosequencing. Environ. Sci. Technol. 45 7173-7179.

Ye, L., and Zhang, T. (2013). Bacterial communities in different sections of a municipal wastewater treatment plant revealed by $16 \mathrm{~S}$ rDNA 454 pyrosequencing. Appl. Microbiol. Biotechnol. 97, 2681-2690.

Yoon, J. W., Lee, K. J., Lee, S. Y., Chae, M. J., Park, J. K., Yoo, J. H., et al. (2010). Antibiotic resistance profiles of Staphylococcus pseudintermedius isolates from Canine patients in Korea. J. Microbiol. Biotechnol. 20, 1764-1768.

Zhang, T., Zhang, X.-X., and Ye, L. (2011). Plasmid metagenome reveals high levels of antibiotic resistance genes and mobile genetic elements in activated sludge. PLoS ONE 6:e26041. doi: 10.1371/ journal.pone.0026041

Zhang, A. Y., Wang, H. N., Tian, G. B., Zhang, Y., Yang, X., Xia,
Q. Q., et al. (2009). Phenotypic and genotypic characterisation of antimicrobial resistance in faecal bacteria from 30 Giant pandas. Int. J. Antimicrob. Agents 33, 456-460.

Conflict of Interest Statement: The authors declare that the research was conducted in the absence of any commercial or financial relationships that could be construed as a potential conflict of interest.

Received: 13 December 2012; paper pending published: 04 January 2013; accepted: 04 April 2013; published online: 14 May 2013.

Citation: Cantas L, Shah SQA, Cavaco LM, Manaia CM, Walsh F, Popowska $M$, Garelick H, Bürgmann H and Sørum $H$ (2013) A brief multi-disciplinary review on antimicrobial resistance in medicine and its linkage to the global environmental microbiota. Front. Microbiol. 4:96. doi: 10.3389/fmicb. 2013.00096

This article was submitted to Frontiers in Antimicrobials, Resistance and Chemotherapy, a specialty of Frontiers in Microbiology.

Copyright (C) 2013 Cantas, Shah, Cavaco, Manaia, Walsh, Popowska, Garelick, Bürgmann and Sørum. This is an open-access article distributed under the terms of the Creative Commons Attribution License, which permits use distribution and reproduction in other forums, provided the original authors and source are credited and subject to any copyright notices concerning any third-party graphics etc. 